\title{
JOHN MURRAY AND JAMES B. TORRANCE ON COVENANT THEOLOGY
}

\author{
DINU MOGA ${ }^{*}$
}

Emanuel University of Oradea

\begin{abstract}
Whatever opinion we might have on the covenants of God with man, we cannot escape the fundamental truth that covenant theology is the best way of presenting the Biblical development of God's revelation in the history of mankind. Therefore, our duty is to learn to think in covenantal terms, because thinking in covenantal terms means to think biblically. When God, in His sovereignty, has chosen to deal with man, He has chosen to do so through two covenants: the covenant of works, made between God and Adam as the representative head of all mankind, and through the covenant of grace, made between God and Christ on behalf of those who were predestined and elected in Christ.
\end{abstract}

KEYWORDS: covenant, federal theology, grace, interpretation, worship

\section{Introduction}

The objective of this paper is to study the subject of covenant theology as seen from the perspective of John Murray and James B. Torrance. The subject of covenant theology is a vast subject and over the last few decades has been widely debated in theological literature. Federal theology, as it is also called, is a system of doctrines that finds its most precise definition in the Westminster Confession of Faith. [J. B. Torrance calls it 'the first postReformation confession to enshrine the 'federal scheme', although a 'mild statement' compared with other more radical views in the federal scheme'. See Torrance (1982:40).] Because of its influence upon the churches of the last three hundred years, the federal scheme has prompted a series of discussions. Some of these were published in order to show the importance and the positive effects which this system had upon the understanding of the unity and continuity of the Biblical revelation with respect to God's relationship with men. But there were others who approached this subject with a very critical attitude, and their intention was not only to show the weak-

* DINU MOGA (MTh in Historical Theology, Westminster Theological Seminary, 2005; PhD in Theology, Babeș-Bolyai University, 2015) teaches Systematic and Historical Theology at Emanuel University of Oradea. Email: mogadinu@gmail.com. 
nesses of the federal scheme, but also to label it the sin of turning God's covenant of grace into a contract.

In this paper, I shall attempt to present these two positions and I shall do this by bringing into consideration the views of John Murray and James B. Torrance on covenant theology. This objective will be fulfilled firstly, through an attempt to summarise their views on covenant theology, secondly, through a comparative study of their positions, thirdly, through a critical assessment of their views and finally through some concluding remarks. The first view to be discussed is that of John Murray.

\section{John Murray on Covenant Theology}

Under this heading I shall consider how John Murray views covenant theology. I shall do this under the following sub-headings: first, the development and importance of covenant theology for John Murray; second, the term 'covenant' and especially John Murray's explanation as well as Scriptural usage; third, the Covenant of Works in John Murray's view; and fourth, the Covenant of Grace in John Murray's view. Having discussed these issues, we shall then draw some final conclusions on Murray's views of covenant theology.

When Murray expounds the theology of the covenant, we see how he distances himself from the other federal theologians and brings his own particular interpretation upon it. He does not want to speak about three covenants or two covenants. He speaks only about one covenant: the covenant of grace. Nevertheless, if the term 'covenant' needs to be used with reference to Adam in his pre-fall condition, then Murray prefers to refer to that relationship as a 'covenant of life' (Murray 1982: 262), because the designation 'covenant of works' fails to communicate its gracious character.

If this is the case with Murray, someone may ask if he can be described federal theologian. Can we place him in the same category with the other federal theologians, such as Thomas Boston, for example, who has spoken about two covenants and refers to the first with the word 'works'? My answer is in the affirmative, but with the stipulation that Murray is an exception within the federal formulation of the covenants. In support for this argument, it is helpful to cite the words of McGowan by which he asserts that 'we must not thereby assume that those who only speak of one covenant are not federal theologians' (McGowan 1984: 41), thus conveying the clear idea of Murray's integration within the sphere of federal theologians. David McWilliams speaks to the same effect and says that by taking this exception to the formulation of covenant theology, Murray does not cause any 'fundamental loss of the basic intent of confessional federalism' (McWilliams 1991: 118). 
Despite the fact that Murray is not inclined to express himself in terms of the covenant of works, his presentation of the Adamic administration is compatible with the view of those who hold to the covenant of works and express themselves in such terms. This is one way of showing that Murray is, indeed, a federal theologian, but looking at what he has to say about the development and importance of covenant theology is another way of further proving his status as such a theologian.

\section{The Development and Importance of Covenant Theology for John Murray}

In his collected writings (Murray 1982: 216; cf. Murray 1972: 199). John Murray describes covenant theology as 'a development of theological thought and construction within the Reformed or Calvinistic tradition'. When he refers again to the aspect of development and progression, he says that 'covenant theology marked an epoch in the appreciation and understanding of the progressiveness of divine revelation' (Murray 1953: 3). For Murray, as for other more contemporary federal theologian it is important to stress these two aspects: tradition and historical development. [See McGowan (1984: 41). McGowan refers to the long history of federal theology as a system and shows with great clarity how 'the system has been developing, changing and adapting throughout the whole course of the long history'.]

We notice that Murray narrows down his definition of covenant theology to the Calvinistic tradition, but he continues immediately to state that by saying so he does not infer that 'God's covenantal relations' have been ignored in other theological traditions. Nevertheless, he stresses the idea that covenant theology is a distinctive feature of the Reformed theological tradition. [See Murray (1953: 3). Compare also McGowan (1997:1, 2). In order to place Boston in his proper historical context McGowan makes, first, a general assertion, saying that 'Covenant theology is a particular expression of Calvinism' and then traces its development in the early part of the 16th century through more or less the same people mentioned by Murray.]

For John Murray, the importance of covenant theology consists in the fact that it recognizes 'the organic unity and progressiveness of redemptive revelation'. It also 'recognizes the fact that redemptive revelation was covenant revelation and that the religion or piety which was the fruit and goal of this covenant revelation was covenant religion or piety' (Murray 1953: 3). We notice, therefore, that for Murray covenant theology is important because it is formulated in Scripture. The Scriptures attach significance to the divine covenants. They describe the way in which God has planned how to purchase and apply salvation for the man lost in his sin.

Referring to the relevance of the development of covenant theology for Owen's teaching, Sinclair B. Ferguson affirms: 'during the sixteenth century covenant theology came to be regarded as a key to the interpretation of 
Scripture and, during the seventeenth century, a key to the interpretation of Christian experience. It brought with it a fresh insight into the unity of Scripture' (Ferguson 1987: 20).

Theology in general, says Murray, must always be undergoing reformation, because the human understanding is imperfect. For Murray, as well as for us, there is always the need for 'correction and reconstruction' (Murray 1953: 5) and these two elements are needed in order to bring our understanding more in line with the Word of God, the Holy Scriptures. But Murray sees that the need for correction and reconstruction should be fulfilled with the help of the classic theologians, not in isolation from them and with an attitude of disregard for their fine and well-articulated systematisation of covenant theology.

\section{The Term 'Covenant'. John Murray's Explanation and Scriptural Usage}

The Definition of the Term 'Covenant'-Covenant or Contract?

According to Murray, God's relationship with men is presented within the Bible in covenantal terms. He shows that the Lord has always covenanted with His people in the words: 'I will be your God and you shall be My people' (Leviticus 26:12).

Referring to the era of Reformation and subsequent times in the development of the covenant theology, Murray shows that the term 'covenant' has been deeply affected by the idea of a 'contract, or agreement between two parties' (Murray 1953: 5).

Therefore, his purpose throughout his writings is to negate the presence of a contract or mutual agreement, in the legal sense of the word, within the concept of a divine-human relationship established through a covenant. In his concluding remarks, Murray shows that, throughout the period of the Reformed tradition, the formulation of a covenant took the form of a fourfold division: contracting parties, conditions, promises and threatening. And the elements of the covenant consist in the Author, the Parties contracting, the Mediator and the Clauses. [See Murray (1982: 217). In order to reach this fourfold division, Murray goes through three major Reformed periods in the development of the term: the earliest period represented by Henry Bullinger, the classic period of Zachary Ursinus, and the period of the more recent times of Charles Hodge.]

His concern becomes to discover whether the notion of 'mutual compact or agreement' provides the proper point of departure for our construction of the covenant of grace. He wants us to see whether a theological study of the Bible will disclose that, in the usage of Scripture, covenant may properly be interpreted in terms of a mutual pact or agreement. Therefore, let us see how he proceeds to expound on this theme. 


\section{The Use of the Term 'Covenant' in Scripture}

In his analysis, Murray embarks on a 'technical' study of the various forms of covenants used in Scripture and shows how it was understood that the idea or pact or contract is not adequate as a definition of the original words 'berith' and 'diatheke'. Murray explains that although the notion of mutual agreement and the idea of contract are central, it does not follow that the idea of compact is central or essential to the covenant relation which God constitutes with men' (Murray 1953: 8, 9). In his opinion a mutual compact is of the essence of covenant when merely human relationship is in view.

For Murray the use of the word 'diatheke' is very significant in the case against the notion of contract, because the translators of the Old Testament, and following them the New Testament authors, did not use the ordinary Greek word 'suntheke', a word for contracts and agreements in which both parties were equal, but rather chose a less common word 'diatheke' which emphasized that the provisions of the covenant were laid down by one of the parties only (Grudem 1994: 515, see also Ferguson 1987: 21). In such a situation, we have to speak about a unilateral covenant.

Murray's exposition continues with an analysis of various forms of covenants described in the Old Testament (Murray 1953: 10-11) and then concludes:

\footnotetext{
We cannot fail to note that what is in the forefront in these cases is not a contract or compact. Strictly speaking, it is not an agreement. Though the persons entering into covenant agree to do certain things, the precise thought is not that of agreement by the people themselves, not a mutual agreement between the people and the Lord. We must distinguish between devising terms of agreement or striking an agreement, on the one hand, and the agreement of consent or commitment, on the other. What we find in these instances is solemn, promissory commitment to faith or troth on the part of the people concerned. They bind themselves in bond to be faithful to the Lord in accordance with His revealed will... We are far away from the idea of a bond as sealed on the acceptance of certain prescribed stipulations and the promise of fulfilment of these stipulations on the condition that other parties to the contract fulfil the conditions imposed upon them (Murray 1953: 10-11).
}

When Murray comes to discuss the covenant, which is specifically divine, the question: 'Does the idea of mutual compact or agreement constitute the essence of a divine covenant?' becomes very urgent for him. From the few instances in the Old Testament he singles out Jeremiah 33:20, 25 and asserts that is this connection the covenant points to the ordinances, power, and faithfulness of God. Mutual agreement, therefore, does not constitute for Murray the essence of a divine covenant. According to Murray, a divine covenant is a sovereign administration of grace and of promise. That which 
provides the governing or constitutive idea of a covenant is not the notion of compact or contract or agreement, but that of dispensation in the sense of disposition. Having established the main thrust of Murray's argument with respect to the nature and usage of covenant concept in the Old Testament, it is now appropriate to turn to a summary of the covenant of works.

\section{The Covenant of Works in John Murray's View}

In his exposition on the covenant of works John Murray's objective is to help us to understand that the Adamic administration must not be interpreted in terms of covenant of works. In order to accomplish this objective, Murray uses three major arguments.

First, it is important to understand that the early covenant theologians did not interpret Adamic administration as a covenant, far less as a covenant of works (Murray 1982: 217-218). He shows that the covenant of works was clearly enunciated in all its essential features in Robert Rollock and finds it very difficult to trace the genealogy of the covenant of works prior to the last decade of the 16th century. [See Murray (1982: 220-222). Murray continues with a presentation of the way in which the Covenant of Works has been formulated by Heyder, Polanus, Perkins, Preston, The Irish Articles of Religion, Westminster Confession of Faith and Catechisms and finishes with the classic Reformed theologians of the 17th century, having Francis Turretin as their representative, when new aspects appear. These new aspects consisted in a departure from the concept of legal covenant and the gracious character of what was still called the Covenant of Works came to be recognized and emphasised; see Murray (1982: 219). Murray refers to Caspar Olevianus and proceeds to explain what went beyond Olevianus' application of the term 'covenant'. Once he gives us a summary of Olevianus' position towards the term 'covenant of works', he concludes saying that it is very likely that Olevianus 'construed the 'first covenant' (God's covenant with Adam) as a special administration to Adam rather than as merely the legal covenant insofar as it applied to Adam'.]

Second, in his second major argument concerning the covenant, based on his exposition on the Adamic administration, Murray asserts (1) that the elements of grace entering into the administration are not properly provided for by the term 'works' (2) that the Adamic administration is not designated a covenant in Scripture. Covenant in Scripture denotes the oathbound confirmation of promise and involves a security which Adamic economy did not bestow. Murray rejects the possible allusion to an Adamic covenant in Hosea 6:7 and insists that there was no covenant prior to the covenant with Abraham (Murray 1982: 219).

Murray defines the 'Adamic administration' in the following way: 
The Adamic Administration is therefore construed as an administration in which God, by a special act of providence, established for man the provision whereby he might pass from the status of contingency to one of confirmed and indefectible holiness and blessedness... The way instituted was that of 'an intensified and concentrated probation... (Murray 1977: 49).

Although Murray is reluctant to call it a covenant of works, his description of this administration is consistent with that made by those who are inclined to make use of the term covenant of works. Adam is created in the image of God as a free, responsible, religious agent. He acts as a representative of the human race. He is promised life if he obeys God's will and death if he disobeys it. Adam is seen by Murray acting as our representative in a "probation period' not in a covenantal position, which, if successfully completed, would have secured him and all represented by him eternal life. [For a different view see Eveson (2001: 66) and Kline (1978: 101-102, 168).]

Third, final argument John Murray addresses is the way in which John Calvin used the expressions: 'the covenant of the law' and 'the legal covenant', which might appear to suggest the Calvin has given support to the doctrine of the covenant of works, but he did not. Calvin also rejected Hosea 6:7 as an interpretation in which allusion might be found to the Adamic covenant, but maintained and taught the doctrine of Adam's representative headship. Therefore, it must be noted, concludes Murray, that the concept of legal covenant is found in Calvin, but is not applied by him to the Adamic administration (Lillback 2001: 276-304). This concept came to be clearly applied by Rollock, who defines the covenant of works, also called the Covenant of Nature, as 'the covenant in which God promises to man eternal life on the condition of good works performed in the strength of nature, a condition which man in turn accepts' (Hughes 1972: 202). From this time on, says Murray, 'the rubric of the Covenant of Works is part of the staple of covenant theology' (Hughes 1972: 202).

\section{The Covenant of Grace in John Murray's View}

For Murray, the main focus is on the Covenant of Grace. He sees this covenant as being almost exclusively the main interest of the $16^{\text {th }}$ century theologians. In his view, the Covenant of Works was but a preface to the unfolding of the Covenant of Grace, which is constitutive of the history of redemption. We shall also notice that one of Murray's greatest concerns throughout his exposition on various covenants is to continue to caution us not to take our point of departure in this covenant from the idea of compact or contract or agreement in any respect whatsoever. This is only to be expected, I think, in view of the manner in which he dealt with the covenant of works. He says: 'It is not contractual in its origin, or in its constitution, or in its operation, or in its outcome' (Murray 1953: 15). 
What he also wants us to know is that the covenant of grace is 'an administration of grace and goodness which emanates from the sovereign good pleasure of God and continues without any modification or retraction of its benefits by the immutable promise and faithfulness of God' (Murray 1953: 14). 'From the earliest period of the Reformation', asserts Murray, 'the Covenant of Grace was conceived of in terms of the administration of grace to men and belonging, therefore, to the sphere of historical revelation' (Murray 1982: 223). Murray would argue that the Covenant of Grace has been dispensed to men for the first time in the promise given to Adam after the fall in Genesis 3:15 and has taken a concrete form in the promise given to Abraham and afterwards progressively disclosed until it reached its fullest realization in the New Covenant made with Christ on behalf of the elect (Murray 1982: 223).

\section{The Nature of the Covenant of Grace}

Under the above scheme, Murray looks at various covenants from the Old Testament and fixes his objective to discover what precisely constituted a covenant and what precisely was the nature of that relation between God and man (Murray 1953: 12).

It is not possible to go into all the details mentioned by Murray, but in his exposition upon the post-diluvian Noahic covenant stated in Genesis 9:9-17, he underlines what he has just proposed that this covenant was an administration of grace and goodness; it was not dependent upon faith or obedience on the part of man (Murray 1953: 14). Nevertheless, Noah was drawn within the scope of its operation and was commanded to do certain things, but the doing of those things on his part represents the response which the grace of the covenant constrained and demanded from him (Murray 1953: 16). To conclude, asserts Murray, this covenant does not in the least suggest mutuality of agreement or compact.

Describing the Abrahamic and Mosaic covenants from Genesis 15:8-18 and Exodus 2:24 Murray makes reference again to Calvin who regarded this covenant as the first covenant administration answering to justification and acceptance with God (Murray 1982: 223).

Insisting upon the unity and continuity of the Old Testament covenants, John Calvin suggested, says Murray, that the Mosaic covenant was not of a different character or governed by a different principle, but was a confirmation of the Abrahamic covenant. The new feature underlined by this covenant is that the promise given to Abraham is fulfilled by Christ in the New Covenant (Luke 1:72; Galatians 3:15ff). Referring to the New Covenant, Murray quotes Calvin in order to show that: 'Even the New Covenant is not so called because it is contrary to the first covenant, but because there is a clearer and fuller manifestation of the gratuitous adoption which the Abra- 
hamic covenant revealed and the mosaic confirmed' (Murray 1982: 224). The formula adopted by Calvin to express the three features of unity, continuity and consummation in Christ was oneness in substance, but differences in mode of administration.

With respect to the conditions of the Abrahamic covenant they must be understood, says Murray, not really as conditions for the bestowal of grace, but as 'reciprocal responses of faith, love and obedience, apart from which the enjoyment of the covenant blessings and of covenant relation is inconceivable' (Murray 1953: 19).

The same is true with respect to the condition of obedience in the Mosaic covenant. In both cases for Murray the keynotes are obeying God's voice and keeping the covenant.

For Murray, the same rule applies to the Davidic covenant. This later development is only expected to 'confirm and intensify' (Murray 1953: 23). what we have found to be the specific character of covenant administration. The progression within this covenant is seen in the occurrence of the messianic promises and in the introduction of a very important feature, namely that of the 'security and certainty' (Murray 1953: 23) of the covenant expressed by David in 2 Samuel 23:5. The passage from Isaiah 42, in which the Servant of the Lord is promised, cannot be overlooked in this connection as well. This time again Murray's emphasis falls upon the fact that 'nothing less than sovereign dispensation and unilateral bestowment will comport with the donation of the servant as a covenant of the people' (Murray 1953: 24). The reason for saying this is again to show the incompatibility of any notion of agreement or compact with the sovereignty of the grace involved and the divine monergism of the action entailed'.

Before Murray explains the fulfilment of the New Covenant in Christ, he suggests a couple of instructive lessons. The first one is with respect to the prophecy of Zacharias through which he refers to the covenant made by God with Abraham. For Murray, the important feature underlined in Zacharias' prophecy from Luke. 1 is that God has remembered 'His holy covenant, the oath which He swore to our father Abraham' (vv. 72, 73). Through his prophecy, we can easily deduce that Zacharias is stressing both the fact that God has been faithful to His covenant promise and that there is unity and continuity in God's covenant revelation and action. There is an inescapable inference that the redemption brought through the coming of Christ has its prototype in the redemption from Egypt by the hand of Moses and Aaron. Perhaps the most suitable verses for a description of the nature of the covenant in the New Testament are the ones written by Paul in Galatians 3:15, 17. Here the emphasis falls upon God's 'immutability, security, inviolability of covenant' (Murray 1953: 26). Based on these arguments Murray draws his first conclusion and asserts that the New Testament con- 
cept of covenant must be seen as 'a promise and dispensation of grace, divinely established, confirmed and fulfilled inviolable in its provisions and of permanent validity' (Murray 1953: 26).

The next important thing for Murray's study of the New Testament covenant is to make a correct interpretation of the difference between what is new in contrast with what is old. His intention is to show that we must not interpret the New Testament covenant as a different covenant to the Old Testament covenant. This does not mean that there are not differences between the two covenants. There are, but these differences must be seen not between two covenants, but within the sphere of one covenant. Here is what Murray concludes:

It is highly significant that the contrast between the new economy and the old is not expressed in terms of difference between covenant and something else not a covenant. The contrast is within the ambit of covenant. This would lead us to expect that the basic idea of covenant which we find in the Old Testament is carried over in the New (Murray 1953: 27).

Therefore, the New Covenant must be seen as an attachment, an expansion of the old covenant and cannot be contrasted with the Old Testament covenant in respect of what constitutes the essence of covenant grace and promise. Murray shows that because our Lord said that His blood was the blood of the covenant that was shed for many for the remission of sins and that the cup of the last supper was the new covenant in His blood, we cannot but regard the new covenant as a 'sum-total of grace, blessing, truth and relationship comprised in that redemption which His blood has secured' (Murray 1953: 27). Therefore, says Murray, covenant must refer to the bestowment and the relationship secured by the sacrificial blood which He shed. It is the fullness of grace purchased by His blood and conveyed by it.

But Murray shows that the new covenant adds another dimension to its essence and this is expressed by Paul in 2 Corinthians 3:6. Paul tells us that the nature of the new covenant is 'the ministration of the Spirit as the Spirit of life, of righteousness and of liberty' (verses 6, 8) (Murray 1953: 28). But most significant about this new covenant, says Murray, is the ministry through which we are transformed into the image of the Lord Himself. In the conception of the writer of the epistle to the Hebrews it is a covenant with a more excellent ministry (Hebrews 8:6). It is a covenant which brings to fulfilment the Old Testament promise and central element of the covenant 'I will be their God, and they shall be My people' (Hebrews 8:10). Murray concludes his study saying that 'the new covenant is covenant as we have found it to be all along the line of redemptive revelation and accomplishment. But it is covenant in all these respects on the highest level of 
achievement... here we have divinity at the apex of its disclosure and activity' (Murray 1953: 29).

With respect to the application of the covenant of grace Murray makes a distinction between its internal essence and its external dispensation. The first corresponds to the effectual call and the second is extended even to the reprobate who are within the visible church and includes the benefits obtained through the proclamation of the Gospel and within the sphere of profession. Thus, says Murray, there are two sides of the one covenant of grace, the one visible to us but the other visible perfectly to God alone.

\section{Conclusions}

The following conclusions will help to bring together the essence of Murray's position on the covenant theology. For Murray, in contrast to other covenant theologians, there is only one covenant and within this one covenant there is unity, continuity and development of the various aspects of the Old Testament covenant of grace until it reached its climax and par excellence fulfilment in Christ whose blood is the seal of the new covenant. Therefore, Christ's fulfilment of the promise of the covenant with Abraham constitutes the New Covenant. And the formula adopted to express these three features was 'oneness in substance but difference in mode of administration'. [See Murray (1982: 225). Murray concludes at this point saying that this tradition has received its succinct formulation in the Westminster Confession of Faith in Chapter VII, Sections V and VI. Commenting on these Sections, Robert Shaw makes a three-point theological exposition and basically says that both the Old and New Testament economies are only two dispensations of the same covenant. All believers, both those under the old dispensation and those under the gospel were and are saved by faith in Christ. But in many respects the New Testament dispensation of the covenant of grace is superior to that which preceded the coming of Christ in the flesh. Full exposition found in Shaw (1998: 133-134).]

As we noted earlier, he defines the covenant of works made with Adam as an Adamic administration. He is reluctant to use the word covenant to describe what took place in Genesis 2, because, according to his understanding, the Bible itself does not do that. With respect to a possible third covenant, the covenant of redemption, Murray prefers to see, as Thomas Boston did (Murray 1982: 237, 238), see also McGowan 1984: 14), that the covenant of redemption and the covenant of grace are but one and the same covenant.

Therefore, using Olevianus' exposition of the covenant of grace, Murray resumes this covenant showing that it is a covenant through which God reconciles us to Himself in Christ and bestows upon us the twofold benefit of gratuitous righteousness in the remission of sins and renovation after God's 
image. This twofold promise belongs to the elect and to them alone. And the faith itself by which we are engrafted into the seed of Abraham is the gift of God freely bestowed by the Holy Spirit. The Holy Spirit prepares the hearts of the elect in due time and through His internal efficacy imparts the gift of faith and repentance. The whole covenant, therefore, is merely of grace. But the gratuitous and unconditional character of the covenant is not construed in any way as prejudicing the demand for faith. Thus, it must be said that for the elect the covenant is absolute and not conditional, and that God fulfils the promise out of His mere mercy and goodness. I shall come to the end of my study on Murray by saying that his presentation is biblical, although in some instances his position can be difficult to sustain. [Murray refers to Robert Rollock and others who said that although the covenant of grace 'might seem to require no condition, for it is called a free covenant... we are to understand that grace here... does not exclude all conditions, but that only which is in the Covenant of Works...' The condition stipulated by Rollock is none other than faith as that which comports with Christ and with God's free grace.]

Having made summary of John Murray's view on covenant theology, I shall now proceed in our study to look at the way in which James Torrance expounds covenant theology. I am going to adopt a similar approach as I have taken in Murray's case so that at the end of this parallel summary we shall be able to see as easily as possible the differences and similarities between these two positions.

\section{James B. Torrance on Covenant Theology}

Professor James Torrance argues from a totally different perspective than that of Professor Murray. There are certain notions in his exposition on covenant theology which would position Torrance on the side of the existential theologians such as Karl Barth. [There are various references to Torrance's position in McWilliams (1991: 111-116).] His opposition towards any possible significance for the legal element within the covenantal context is one these notions. His reluctance to accept a distinction between the covenant of works and the covenant of grace and also his agnostic attitude towards the development of the idea of the covenant of redemption is another. And last but not least, his bitter opposition to the notion of limited atonement is definitely a clear indication that Torrance speaks from the perspective of Barthian theology.

For Torrance, as for the others from his category, federal theology constituted a movement away not only from the older Scottish tradition of Knox, the Scots Confession, the pre-Westminster confessions, and the theology of Calvin, but also a movement away from the New Testament (Torrance 1983: 92). 


\section{The Rise of Federal Theology in James Torrance's View}

When Torrance sets off to explain the rise of federal theology, he has at least two purposes in mind: firstly, to prove that the late sixteenth century covenant theology does not have its roots in Calvin, or in Knox and the Scots Confession of Scotland. Secondly, to show that with the rise of federal theology the whole of Scottish theology and worship were about to be changed in a dramatic way, turning freedom in worship into a worship which was 'controlled and directed by the theology which lies behind it' (Torrance 1970: 52).

How does Torrance proceed to do this? First of all he discusses the way in which federal theology has departed from the theology of Calvin. He sees a difference between the way in which Calvin understood the meaning of the word covenant and the way in which it was understood by the federal theologians of the late sixteenth century and afterwards. This is how he explains this change of meaning.

In his first argument, Professor Torrance is concerned to show in repeated instances that the Latin word foedus-covenant, from which the word federal comes, has been misunderstood by the federal theologians. This word, says Torrance, can mean both 'covenant' and 'contract'. It is 'a word which was rich in theological significance as well as a revolutionary symbol in a nation struggling for freedom' (Torrance 1981: 226).

Because it can mean both, says Torrance, the federal scheme has introduced a distinction between the covenant of grace and the covenant of works, which was 'unknown to Calvin and the Reformers' (Torrance 1970: 61). Torrance maintains that for Calvin 'all God's dealings with men are those of grace' (Torrance 1970: 62). In conclusion, we are led to understand at this point that the seventeenth century theologians, due to a misinterpretation of the word foedus, have interpreted God's dealing with men in terms of a contract not a covenant, turning God's dealing with men into a legal relationship.

Torrance's second major argument shows that this misunderstanding has occurred against the background of political and social upheavals which took place in Scottish history, and also in France, England, and New England, of the late sixteenth, seventeenth, and eighteenth centuries. In the people's revolt against 'all forms of 'catholic' authoritarianism' (Torrance 1970: 51) men began to make 'bands', 'pacts', 'contracts', 'political leagues', in order to defend their freedom. So as a result of these 'political struggles for religious and civil liberty' (Torrance 1982: 231). coupled with this misunderstanding of the word foedus, the Biblical interpretation, says Torrance, which has been the teaching of Calvin and the 'heart of the teaching of the Reformation', began to change and to be seen in legal contractual terms. 
These struggles, explains Torrance, led to contractual ways of thinking about God's relation to men and to legalistic interpretations of Calvinism, which were to have a very profound effect upon Scottish religion and many of Scotland's most able theologians in the years to come. Torrance asserts that this idea of social covenanting was so persistent that it provided a context in which Reformed theology was to be 'recast as federal theology' (Torrance 1970: 53).

\section{The Meaning and Interpretation of the Term 'Covenant' in James Torrance's View}

Torrance explains that the Bible describes many forms of covenants and they are all fall into two categories: bilateral (suntheke) and unilateral (diatheke) covenants. This difference is important from a theological point of view, says Torrance, because God's dealings with men in Creation and Redemption-in grace-are those of a covenant 'diatheke' and not of a contract 'suntheke' (Torrance 1982: 229).

Torrance shows that there is a precise difference between a covenant and a contract. In a contract we have a 'legal relationship in which two people or two parties bind themselves together on mutual conditions to effect some future result' (Torrance 1982: 229). But a covenant is a promise binding two people or two parties to love one another unconditionally (Torrance 1970: 54). Torrance underlines the fact that the Bible represents God's covenant as a unilateral covenant, and that God's relationship with man in covenant is a relationship based on love. Therefore as far as Torrance is concerned the concept of contract must be avoided at all cost.

So, for the sake of clarity and completeness, let us summarize Torrance's view on the meaning of the word 'covenant'. With reference to God's relationship with Adam Torrance denies the existence of a covenant between God and Adam, in terms of a promise made upon condition of obedience, and calls that relationship a covenant of love, which for Torrance means that in grace, or in covenant love, God creates Adam for covenant love and then lays him under unconditional obligations, warning him of the consequences which would follow if he transgresses these commandments (Torrance 1983: 89, 90). His first conclusion would be to say that God is a Covenant-God not a contract-God (Torrance 1982: 230). In His love God the Father made a covenant with His Son Jesus Christ for us, and in His Son, God bound Himself to man and man to Himself. God then summons us to respond in faith and love to what He has done so freely for us in Christ.

Professor Torrance wants us to avoid turning grace into conditional grace or legalism grace, which loses the meaning of grace (Torrance 1982: 230). Covenant love is unconditioned by any considerations of worth or merit and is unconditional in the costly claims it makes upon us. 
Torrance also shows that in Biblical terms covenant always places grace prior to the obligations of law and human obedience. The order is: 'I am your God, therefore keep My commandments'. But federal theologians, says Torrance, because of their doctrine of election, put it the other way around: 'If you keep the law, God will love you'. For Torrance this means that the covenant has been turned into a contract and has made God's grace conditional on men's obedience (Torrance 1982: 230). It is therefore important for Torrance to show that although there are obligations in a lovebased relationship, such as in marriage, these obligations of love are not conditions of love (Torrance 1982: 231).

\section{James Torrance's Positive and Negative Evaluation of Federal Theology}

Torrance maintains that the influence of federal theology was felt in the theological orientation and worship of the church. For Professor Torrance the man who first discovered these dramatic changes was John McLeod Campbell, whom he describes as 'a godly man with the heart of a pastor and an evangelical concern to instruct his flock in the Gospel of grace' (Torrance 1973: 296).

In his evaluation of federal theology, Torrance recognises some positive aspects of federal theology and at least four serious weaknesses which have deeply influenced the concept of God in Scottish religion.

On the positive side his remarks are limited only to the causes which prompted the rise of federal theology. These causes are: (1) a concern for biblical exegesis and the desire to see the fundamental unity of the Bible; (2) a concern to discern the historical nature of revelation and see the movement of God in history, (3) a concern to have a carefully wrought out systematic presentation of Reformed thought; (4) an attempt to hold together divine predestination and human responsibility, the sovereignty of God and human activity, the rightful claims of God and the freedom of man; (5) a concern to provide a language of communication in terms of which the great doctrines of the faith were presented and gripped the imagination of many generations in the political struggles of the Scottish nation.

But on the negative side Torrance summarises a couple of significant features of the federal scheme which, in the case of McLeod Campbell, led to a break with the federal scheme.

According to Torrance the first negative influence of the federal scheme is seen in a deep-seated confusion between a covenant and a contract. This confusion is exemplified in a failure to recognize that the God and Father of our Lord Jesus Christ is a covenant-God and not a contract-God. In Torrance's view this confusion was one of the roots of that kind of legalism which has had such a deadening effect on Scottish religion. Torrance sees 
that this confusion between a covenant and a contract has gone wrong in placing the imperatives before the indicatives, replacing the love relationship with the law relationship.

The second important negative feature seen by Torrance in the federal scheme is represented by a radical dichotomy between the sphere of Nature and the sphere of Grace. This has led to the view that the Mediatorial work of Christ is limited only to the elect. This view, says Torrance, fails to take account of the headship of Christ over all creation and all nations as Mediator. In both Old and New Testaments, the order is grace over law. Too often in western theology, says Torrance, we see the assertion of the priority of law over gospel, the priority of nature over grace. Torrance shows that John Owen and Jonathan Edwards took this to its logical conclusion in teaching that justice is the essential attribute of God, but the love of God is arbitrary-God is related to all men by law as Judge, but only to the elect in grace. In conclusion, Torrance asserts in powerful language that this might be the logical corollary of federal Calvinism, but it is not true to the New Testament.

In the third place, Torrance asserts that the relation between forgiveness and repentance is another problem which highlights some of the consequences of the rise of federal theology (Torrance 1970: 57). In Torrance's view forgiveness takes priority over repentance, a priority seen in the fact that Christ died for us while we were yet sinners. But according to Torrance the fallacy here was to invert the evangelical order of grace and make repentance prior to forgiveness, while in the New Testament forgiveness is logically prior to repentance. This inversion has prompted the seventeenth century divines to make a distinction between what they called legal repentance-where the form is: 'If you repent, you will be forgiven'. 'This do and you shall live!' and evangelical repentance-where the form is 'Christ has done this for you, therefore repent!' (Torrance 1996: 7).

But the most serious critique brought against the federal theology is with regard to the doctrine of double decree which, says Torrance, thrusts up the doctrine of a limited atonement. According to Torrance the lack of assurance has been one of the greatest effects produced by limited atonement. This has led McLeod Campbell, explains Torrance, to a close consideration of the extent of the atonement. Eventually, McLeod Campbell arrives at the conviction, says Torrance, that unless Christ died for all, there is no foundation for the assurance McLeod Campbell demanded and saw to be essential to true holiness (Torrance 1973: 298).

Within the content of his exposition Professor Torrance brings in discussion a series of other major doctrines, such as: the doctrine of God, the doctrine of the incarnation and the doctrine of election, and he does this in order to prove that all these doctrines are negatively affected by the federal 
scheme. Therefore, Professor Torrance proposes the following scheme for the atonement.

In Torrance's view the Christian logical starting point is the doctrine of the incarnation and the doctrine of God (Torrance 1983: 93). He would assert that the doctrine of the Incarnation shows us that God came as man in Christ and Christ, as God and as man, experienced the rejection of those who hated Him, but whom He loved to the end in spite of their hatred (Torrance 1983: 85). Due to this reasoning, Torrance maintains that the doctrine of God must be interpreted in the light of the incarnation (Torrance 1983: 86).

For Torrance, the atonement is the work of the Triune God who loves all His creatures. It is obvious that Torrance is speaking here about the universal love of God, because he continues to say that if we are true to the New Testament, we must assert that the Father loves all His creatures, Christ died for all, but none can come to the Father except the Spirit draw him (Torrance 1983: 84). The teaching of John Owen, suggests Torrance, that God does not love all people (Torrance 1983: 84) is an argument which 'runs in the face of the plain teaching of the Bible that God is Agape (Torrance 1983: 85).

Torrance's argument on the universal love of God is then followed by the question: Does this mean that we abandon any doctrine of election? Certainly not, says Torrance. But for him the doctrine of election must be interpreted in a christological way. The principle is expressed in the words 'the one and the many', 'the one for the many', 'the many in the one' (Torrance 1983: 86). Election is thus in and through Christ and is both corporate and personal (Torrance 1983: 87). Interpreted in this christological way the doctrine of election is the good news that our salvation is by grace alone and is from beginning to end the one work of the one God, Father, Son and Holy Spirit (Torrance 1983: 87).

\section{The Effects of Federal Theology upon the Church}

In each of these evaluations of the federal scheme Torrance sees an 'impoverishment and restriction' on the concept of grace-a shift of emphasis from what God has so freely and unconditionally done for all men in Christ, to a more subjective interest in what we have to do. As expressed earlier such an approach, says Torrance, produced a deep lack of Christian assurance in that it left people tortured by the question 'Am I one of the elect? Have I fulfilled the condition of grace?' This lead to a preaching preoccupied with sin, judgment and repentance. There was also an emphasis on the element of self-examination in prayer which deprived people of joy and peace and gratitude and praise for the forgiveness so freely given in Christ. 
In the federal scheme, says Torrance, the whole focus of attention moves away from what Christ has done for us and for all men, to what we have to do IF we would be in covenant with God. For preaching this means that the emphasis falls less on the indicatives of grace and more on the imperatives of repentance, obedience and faith. The sacraments, baptism and the Lord's Supper, are not so much seen as seals of the Gospel, evangelical ordinances, but rather as seals of our faith, or seals of our repentance. With the emergence of this change in emphasis, the need for repentance and faith become conditions for coming to the Table.

In Torrance's exposition, the changes in theological emphasis of the federal scheme are also represented as having a negative influence on the whole content of worship. Worship can become 'less and less a joyful grateful believing response to the objective realities of Christ and the Gospel, to a more inward-looking subjective preoccupation with penitence and personal assurance of election (Torrance 1983: 71).

\section{Conclusions}

From this summarized presentation of Professor Torrance's view on covenant theology it becomes very obvious that he bitterly opposes covenant theology and his entire approach to it is a critical one. His major purpose is to prove that federal theology is incompatible with the gospel of God's free grace in Christ, because it is presented to us in contractual terms. And when the covenant of grace is viewed in contractual terms, grace is made to be conditional and 'the whole focus of attention moves away from what Christ has done for us and for all men, to what we have to do IF we would be in covenant with God' (Torrance 1970: 69). God is no longer a God of love but a Judge, a harsh Law-Giver, ready to inflict punishment upon those who do not fulfil the conditions of His covenant.

For Torrance federalism is a subjective and inward-looking theology, creating unhappiness for those who were subjected to it. He goes as far as to say that this teaching is not the product of New Testament teaching, but a departure from it, and does not finds its roots in the teaching of Calvin and of the Reformed tradition, but it is a departure from Calvin and a distortion of Reformed theology through the introduction of limited atonement. It is a product of an incorrect interpretation of the Latin word 'foedus' and the result of the socio-political struggles of the late sixteenth century, when the people who searched for their freedom started to think about God in contractual terms. The effects of this new approach, says Torrance, were disastrous for preaching, worship and Christian living in the centuries to follow. For Professor Torrance, the only way to recover from this situation is to return to a correct understanding of the doctrine of the Trinity. We need to insist upon the priority of grace over law, suggests Professor Torrance. 
Having summarised both views on covenant theology it is now time to turn to a comparative and critical assessment of these two views.

\section{A Comparative Study between John Murray and James B. Torrance}

One very evident difference between John Murray's view and that of J. B. Torrance is with respect to the origin of federal theology. If John Murray argues that federal theology has its roots in Calvinistic tradition, J. B. Torrance would argue the opposite and say that federal theology is a serious departure from the Calvinist tradition.

Another element of difference is with respect to the way in which these two men interpreted the covenant of works. While Murray refuses to call it a covenant of works, but refers to it as an Adamic administration, Torrance is totally opposed to the notion of covenant and says that the occurrence of this covenant is the result of a confusion between a covenant and a contract. It never existed in the Bible. The best Torrance can do is to call it a covenant of love, emphasising that God acted in grace and love towards Adam and placed on him no conditional obligations to fulfil. For both views we can use the same argument and say that in Genesis 2 we have all the essential parts to be able to speak about the presence of a covenant of works. This issue will be expounded in more detail in my critical assessment on this matter.

But one significant area of difference between Murray's and Torrance's views is with respect to the rise, development and importance of covenant theology. Murray sees covenant theology as a development and a construction within Reformed or Calvinistic tradition. For Murray covenant theology is a distinctive feature of Reformed theological tradition. Murray also sees covenant theology as being important, because it is formulated in Scripture and if we wish to implement corrections and reconstructions to this scheme, we must do it within the context of the classic theologians. But none of these features are accepted by Professor Torrance. Covenant theology is an estrangement from Scripture, a product of linguistic confusion and of a socio-political unrest within the seventeenth century. The federal scheme, far from being important to the believer, has as its fruits only lack of peace, joy and assurance. In his view what Scottish theology needs is a return to its old tradition, the tradition of the Scottish confession of 1560 .

One small part of similarity between Murray and Torrance is in the way in which they make a difference between 'diatheke' and 'suntheke'. Both argue in the same way and acknowledge that God's dealings with men are in terms of 'diatheke' not 'suntheke'. But although Murray would argue for the use of the word 'diatheke', Torrance still charges federal theologians with the use of the contractual language conveyed by the word 'suntheke'.

It is also interesting to notice how Torrance argues against something which Murray did not affirm. In his articles, Torrance often asserts that the 
federal theologians were guilty of a deep seated confusion between a 'covenant' and a 'contract' and adopted as standard definition that a covenant is a contract between two parties based on mutual conditions. We have shown at great length how Murray urges us to avoid exactly the same thing and proves why we should not use the language of a mutual agreement or contract.

\section{A Critical Assessment of Both Views}

The first aspect analysed under this heading will refer to Professor Murray's position with regard to the covenant of works, a designation which he prefers not to use. We have shown at the appropriate moment his reasons for adopting this attitude. However, Murray's contrary attitude towards the use of the word 'covenant' for the pre-redemptive relationship between God and man can be challenged due to the fact that even though the term 'covenant' is not used in Genesis 2, it can be still used due to the fact that it conveys biblical truth.

In his treatise on Boston, Andrew McGowan calls this argument 'a linguistic argument' and shows how Boston likened the use of the term 'covenant' with the use of the terms 'trinity' or 'sacrament' which do not occur in Scripture as well but are found useful because they convey biblical truth. [See McGowan (1984: 10); also Shaw (1998: 124) where he draws attention to 'all the essential requisites of a proper covenant' in Genesis 2: 15, 17. After he lists them all, he draws the conclusion: 'We are, therefore, warranted to call the transaction between God and Adam a covenant'. Likewise, in an even more definite terms Dumbrell (1984: 44).]

Lloyd-Jones also stresses the fact that, by putting Adam into the Garden and by telling him that if he did certain things, he would have a certain reward, God uses the language of a covenant. It is called a covenant of works because Adam's inheritance of this promise was entirely dependent upon his works, upon what he did (Lloyd-Jones 1996: 226). In a similar language Norman Shepherd explains that whether you call this covenant a covenant of life or a covenant of works the idea is the same, because life is promised on the condition of works (Shepherd 2000:25). The new covenant, by way of contrast, promises life on the sole condition of faith. So due to the validity of this reasoning, I do not see why we are not justified in speaking about a covenant between God and our first parents in the Garden of Eden.

But the use of this term can also be defended with a theological argument which sees the imputation of sin to all mankind as being dependent on the existence of a covenant between God and Adam (McGowan 1984: 10). If we say that there was no covenant between God and Adam in that pre-redemptive relationship, then on what basis can we suggest that Adam's sin was passed on to all mankind? If God did not make a covenant of works 
with Adam on what basis I am corrupted by original sin becomes a pertinent question for all of us.

One last argument in favour of the use of the term covenant is found in Hosea 6:7, where Israel's covenantal unfaithfulness is compared to that of Adam. In the words of Hosea: 'They, like Adam, have transgressed the covenant' it is clearly implied that God made a covenant with Adam, and that Adam violated it. Besides the verse from Hosea, we find that in Romans 5: 12-21 Paul looks at both Adam and Christ and sees them as heads of the people whom they represent, something that would be entirely consistent with the idea of Adam being in a covenant before the fall. John Murray might have said that he has a strong textual support for the rejection of this interpretation, but even that argument can be explained, and the logical interpretation of this verse leaves no room for representing 'man' with somebody other than Adam. [For an explanation on textual variants see Grudem 1994: 516 on footnote no. 1 referring to Hosea 6:7. In favour of the meaning 'like Adam', referring to the first man, see also Dumbrell (1984: 45-46); McComiskey (1988: 215, 216); and Robertson (1980: 22-25). For an interpretation against the meaning 'like Adam' and in favour of 'at Adam', referring to a place, see Andersen and Freedman (1980: 435ff).]

On the other hand, Professor Torrance maintains that the schema of the Westminster Confession of Faith, in which a distinction between the covenant of works and the covenant of grace is made, leads to all sorts of departures from a correct understanding of God, of grace and of the Holy Spirit (Torrance 1982: 45). His most serious allegation is the denial that there ever was such thing as a covenant between Adam and God. But we have already shown that in Genesis 2 we have all the essential parts of the covenant. It seems clear that in the Garden of Eden there was a legally binding set of provisions that defined the conditions of the relationship between God and man. If there had been no conditions and no covenantal terms, Adam would have not been put out of the Garden.

With regard to the doctrine of the Covenant of Works, Torrance implies that through the doctrine of the Westminster Confession of Faith God is represented as a contractual God which in turn denies that God is related to all men in love and grace. Here Torrance charges John Owen and Jonathan Edwards with misunderstanding this, and as a consequence they presented God's dealings with men in terms of a contract not of a covenant. In his view, this interpretation leads to great confusion between a covenant and a contract.

In response to this charge we need to show a few things which Professor Torrance fails to see. Firstly, the Confession will always maintain a good balance between the gracious and legal aspects presented in God's dealing with man. The legal aspect cannot be neglected because the relationship 
between man and God has been and always will be one between a Creator and His creature. God is infinite and everlasting and our first parents were created as finite beings. Due to this distinction, I see no problem in affirming that our first parents were in a legal relationship to God. But as McWilliams notices, quoting the Confession, even this legal relationship was never static and impersonal (McWilliams 1991: 110). Even though God has created them in a legal relationship to Himself, He has written His Law in their hearts, and bestowed upon them knowledge, righteousness and true holiness. This condition places man naturally and necessarily under the law of God (Shaw 1998: 123). In his prelapsarian condition man had the power to fulfil the legal terms of the covenant made by God with him as well as the power to transgress it.

With reference to the gracious aspect we have seen that the federal theologians do not deny the presence of God's grace towards man, even before he transgressed the terms of the covenant of works, because man could have not established any contact with God if God had not graciously condescended to deal with him by way of covenant. God has been under no obligation whatsoever to enter into a covenant relationship with Adam and through him with all mankind.

Discussing Owen's view on the covenant of works, Sinclair Ferguson notices how important it was for Owen to teach that there is the grace of promise even in the covenant of works, although it is not the covenant of grace' (Ferguson 1987: 23). This emphasis on grace on Owen's part is extremely important in view of the critical comments made by Professor Torrance.

David McWilliams also comments very conclusively with respect to the nature of the grace man needs before and after the fall and shows that prior to fall the grace of God was metaphysical (creation) grace and after the fall grace was ethical (redemptive) grace (McWilliams 1991: 111). Torrance fails to see that both grace and law are absolutely essential in God's character. What Torrance does is to accentuate grace to such an extent that he distorts the biblical revelation of who God is. The God of the Bible is both the God of grace and the God of law, the God of wrath and the God of love. We cannot accept the picture of a God who is only grace but does not place any righteous demands, any conditions, on those upon whom He bestows His grace.

With regard to the charge brought against John Owen, Jonathan Edwards and other English Puritans who, Torrance said, caused confusion in their understanding of the Latin word foedus, it is hard to accept. We all know how well these people mastered not only Latin, but Greek and Hebrew as well. If anyone has ever understood the meaning of the Latin, Greek and Hebrew words for covenant, then these theologians did that with 
great certainty. Discussing again the way in which Owen understood the meaning of the original words for covenant, Sinclair Ferguson points to the fact that Owen realised only too well that the word 'suntheke' implies that the covenants of God are conditional. Sinclair Ferguson tells us that Owen opposed this view when it appeared in John Goodwin's Redemption Redeemed (1651). Ferguson also shows us that Owen was aware of the fact that his readers understood the word 'covenant' as a legal contract made between two parties when they entered into an agreement, but he warned them that biblical covenants do not always involve precisely the same elements (Ferguson 1987: 21, 22). Thus, Owen can in no way be accused of these charges as he is very careful to offer his contemporaries a correct analysis on these words and the nature of God's covenant with man.

But the most serious charge is brought by Professor Torrance against the doctrine of double decree which, he says, resulted in the doctrine of limited atonement. J. B. Torrance argues that the place of election in the ordo salutis is correct in Calvin, but mistaken in the federal theology, represented by the Confession. Torrance would say that the reason for being correct in Calvin is due to its placement at the end of Book three of the Institutes, after he had done his work on Christology. On the same subject of limited atonement Torrance asserts that although Calvin taught a doctrine of a 'doubled decree' he did not allow this to lead him to teach a doctrine of 'limited atonement' in the manner of the later Calvinists. With regard to his comments about the way in which Calvin placed the chapter on election in his Institutes, I can only say that this argument does not have much weight as long as this doctrine is expounded by Calvin. Calvin could have chosen to place it somewhere else without thinking too much about any possible effect on its interpretation later on. I think that Norman Shepherd's comments on the subject of covenant and election are very important and straight to the point (Shepherd 2000: 79-91). If we look at election from the perspective of covenant, election can be understood as grace and we can preach the Gospel to all people 'as a mixed multitude of elect and reprobate with a view towards not separating them'. From the perspective of a covenant we are allowed the freedom to say that we are dealing with mysterious things as we do not know God's decree as He knows them (Deuteronomy 29:29). Shepherd concludes that in light of the covenant, we learn that the particularistic doctrines of Calvinism are pure grace and not a mixture of blessing and curse'.

But I wish to make one or two comments on Torrance's critical position about the way in which the federal scheme influenced the worship in the church and the participation at the Lord's Table. Firstly, Torrance criticises the inward looking and subjective aspect of federal theology, an aspect which creates much unhappiness in worship. Secondly, in his comments 
Torrance does not seem to stress the need for repentance and faith as conditions for coming to the Table.

Before I say something on these two matters I wish to underline that my intention is not to comment on the practical aspects characteristic to every gathering of the Lord's people. These are very diverse and open to debate. All I wish to do is to draw our attention to a fundamental principle which, in my opinion, seems to be undermined by Professor Torrance. My question is: Does Professor Torrance suggest that these two elements are not absolutely vital for us when we come to celebrate the Lord's Supper?

In his discussions about worship in the church, Torrance does seem to move away from the idea that we are responsible for the way in which we present ourselves at our communion around the Lord's Table and in our worship before God. He does not want us to look at all at the way we worship and how we worship, but to look at what Christ is doing, and what He has done for us and what He is continuing to do for us (Torrance 1996: 8).

Thus, Torrance places too much emphasis on the christological aspect, interpreting every doctrine in order to fit his Christology, and does not pay too much attention to the particular context of each doctrine. I am not implying by this that we should not relate our doctrines to our understanding of Christ. The Person and work of Christ are fundamentally important to our understanding of the doctrines, but it is equally important to understand these doctrines within the general context of the Bible.

I would say that both these things are equally important. We cannot avoid emphasising the need for repentance and faith as conditions for coming to the Table. There must be also a constant concern that the manner in which we worship God is consistent with His character and attributes.

The apostle Paul is very clear on this topic in 1 Corinthians chapter 11 where, speaking about the manner in which we should approach the Lord's Table, he says: 'But let a man examine himself, and so let him eat of that bread and drink of that cup. For he who eats and drink in an unworthy manner eats and drinks judgement to himself, not discerning the Lord's body. For this reason, many are weak and sick among you, and many sleep' (vv. 28-30). When Paul asks us to examine ourselves, he asks us to look into our lives and take account of the manner in which we live our Christian lives. If we are not worthy to come to the Lord's Table, it is better to refrain from doing that, as a sign of respect for the significance of this ordinance and as a sign of repentance for our sins. In failing to do so we expose ourselves to God's judgement, which has been, according to what Paul says, evident among the Corinthians. Therefore, I believe that there is a need to make the distinction between those who can come to the table and those who cannot. And repentance and faith is the condition. 


\section{Concluding Remarks}

As we approach the final part of this paper, I hope that it has been shown that whatever opinion we might have on the covenants of God with man, we cannot escape the fundamental truth that covenant theology is the best way of presenting the Biblical development of God's revelation in the history of mankind. Therefore, our duty is to learn to think in covenantal terms, because thinking in covenantal terms means to think biblically. When God, in His sovereignty, has chosen to deal with man, He has chosen to do so through two covenants: the covenant of works, made between God and Adam as the representative head of all mankind, and through the covenant of grace, made between God and Christ on behalf of those who were predestined and elected in Christ.

I do not think I can stress enough the truth that God's grace is present and visible all the way from the first step God made in His covenant with Adam until the last moment of God's fulfilled covenant of grace in Christ. In saying this, we affirm the truth that federal theology is a theology of grace which presents itself to us with basically two parts, promise and obligation. All the blessings of the covenant are ours as gifts of sovereign grace. When we say that salvation is by grace through faith we in fact refer to the two parts of the covenant: grace and faith, promise and obligation. The gifts of grace cannot be received without obligations, but when they are received they are also not meritorious. Actively living out our Christian faith is not a meritorious achievement. Our obedience to the demands of God's Word is not an obedience of merit, but an obedience of faith. To obey God's Word means to be faithful to the Lord. This truth comes out in plain and clear terms in the writing of the apostle Paul in Romans 9:32 where he speaks about the righteousness of faith and even more clearly in the well-known passage from Hebrews 11 where the patriarchs' obedience was a result of their faith in the promises of God (Hebrews 11:8, 17,33). The apostle James looks as well at the relationship between faith and obedience manifested in our active living. A parallel passage is Mathew 7:21-29 where we are clearly shown that to be faithful to the Lord means to do the will of the Lord.

Finally, it must be also said that federal theology is not free from errors. As Murray has told us this system of doctrines needs reformation and reconstruction, because human beings are imperfect. Therefore, the federal theology of one theologian has differed from the federal theology of another theologian. However, all changes must be considered if these changes will bring our understanding more in line with the Word of God, the Holy Scriptures. 


\section{Bibliography}

Murray J (1953) The Covenant of Grace. London: Tyndale Press.

Murray J (1982) The Theology of the Westminster Confession of Faith. In Collected Writings, volume 4. Edinburgh: Banner of Truth.

Murray J (1982) Covenant Theology. In Collected Writings, volume 4. Edinburgh: Banner of Truth.

Murray J (1977) Adamic Administration. In Collected Writings, volume 2. Edinburgh: Banner of Truth.

Torrance JB (1982) Strengths and Weaknesses of the Westminster Theology. In Heron A (ed) The Westminster Confession in the Church Today. Edinburgh: St. Andrew Press.

Torrance JB (1996) Worship, Community and the Triune God of Grace. Carlisle: Paternoster.

Torrance JB Introduction. In McLeod JC (1996) The Nature of the Atonement. Edinburgh: Handsel Press.

Articles

Torrance JB (1981) The Covenant Concept in Scottish Theology and Politics and its Legacy. SJT 34(*): 225-243.

Torrance JB (1973) The Contribution of McLeod Campbell to Scottish Theology. SJT 26(*): 295-311.

Torrance JB (1983) Incarnation and Limited Atonement. Evangelical Quarterly $55\left(^{*}\right): 83-94$.

Torrance JB (1970) Covenant or Contract? A Study of the Theological Background of Worship in Seventeen-century Scotland. SJT 23(1): 5176 .

\section{Secondary sources}

Books

Dumbrell WJ (1984) Covenant \& Creation. Exeter: Paternoster Press.

Grudem W (1994) The Covenants Between God and Man. In Systematic Theology. Leicester: Inter-Varsity Press.

McComiskey TE (1988) The Covenants of Promise, A Theology of the Old Testament Covenants. Leicester: IVP.

Ferguson SB (1987) John Owen on the Christian Life. Edinburgh: Banner of Truth.

Lillback PA (2001) The Binding of God: Calvin's Role in the Development of Covenant Theology. Grand Rapids: Baker \& Carlisle: Paternoster.

Shaw R (1998) An Exposition of the Westminster Confession of Faith. Fearn: Christian Focus Publications.

Eveson P (2001) The Book of Origins. Darlington: Evangelical Press.

Robertson OP (1980) The Christ of the Covenants. Phillipsburg, PA: P\&R. 
Shepherd N (2000) The Call of Grace: How the Covenant Illuminates Salvation and Evangelism. Philipsburg, NJ: Presbyterian \& Reformed.

Kline MG (1978) The Structure of Biblical Authority. Grand Rapids, MI: Eerdmans.

Andersen FI and Freedman DN (1980) Hosea, A New Translation with Introduction and Commentary. Garden City, NY: Yale University Press.

Lloyd-Jones DM (1996) The Covenant of Grace in the Old Testament \& The Covenant of Grace in the New Testament. In God the Father, God the Son, volume 1: 224-244. London: Hodder \& Stoughton.

McGowan ATB (1997) The Federal Theology of Thomas Boston. Carlisle: Paternoster.

Articles

Torrance JB (1981) The Vicarious Humanity of Christ. In Torrance TF (ed) The Incarnation. Edinburgh, pp. 127-147.

Murray J (1972) Covenant Theology. In Hughes PE (ed) The Encyclopaedia of Christianity, volume 3. The National Foundation for Christian Education, Wilmington, DW, pp. 199-216.

McWilliams D (1991) The Covenant Theology of the Westminster Confession of Faith and Recent Criticism. WTJ 53(*):109-124.

McGowan ATB (1984) Federal Theology as a Theology of Grace. The Scottish Bulletin of Evangelical Theology 2(*): 41-50.

[This article was published previously is Moga D (2008) Studies in Historical Theology. Oradea:

Emanuel University Press, pp. 39-89.] 